\title{
Public space, public art and public pedagogy
}

Nick Schuermans, Maarten Loopmans, Joke Vandenabeele

This article has been published as: Nick Schuermans, Maarten P.J. Loopmans \& Joke Vandenabeele (2012): Public space, public art and public pedagogy, Social \& Cultural Geography, 13:7, 675-682

\section{Public space and public art}

Over the last two decades, social and cultural geographers have broadened and deepened their interest in art (Hawkins 2012). While geographers used to be mainly interested in the spatial imaginaries deployed in artworks, they have also started to focus on the spatialities of its production (Neate 2012), consumption (Cresswell 1992) and exchange (Molotch and Treskon 2009). Inspired by the burgeoning fields of visual studies and non-representational geographies, geographers have realized that art should not always be viewed through the eyes of a detached scholar, but considered in the context of embodied emotions and material practices (Hawkins 2010a, Daya 2011). For this reason, they have expanded their methodological toolbox to encompass new approaches to the geographies of art (Rose, 1996; Rose, 2006; Butler, 2006; Lombard, 2012) .

At the same time, there has been an explosion in the range of arts under study. In the past, social and cultural geographers mainly concentrated on traditional landscape art and other form of 'high' visual culture (Rees 1976, Cosgrove 1985). In the current literature, there is also attention paid to performance (Pinder 2011), installation (Hawkins 2010a), photography (Hawkins 2010b, Lombard, 2012), monuments (Johnson 1995), sculptures (Morris and Cant 2006), plays (Daya 2011), sound art (Butler, 2006, DeSilvey 2010), community art (Rose 1997) and street art (McAuliffe 2012). Importantly, a lot of these artistic practices are not on display in museums and galleries, but performed or materialized in streets, squares and other public spaces (Miles 1997; Amin 2008). We term these 'public art'.

Most geographical engagements with public art revolve around a number of interrelated claims concerning its place-making potential (Hall and Robertson 2001; Zebracki et al. 2010). A first claim is that public art can contribute to the economic development of neighborhoods, cities and city-regions (Landry and Bianchini 1995; Currid 2010). By the 1980s, the installation of art in public spaces became increasingly justified in terms of its supposed contribution to urban revitalization (Sharp et al. 2005). The underlying idea was that artworks would attract tourists and investors (Harvey, 1989; Hall and Robertson 2001: 5). More recently, the creative cities literature has revived this by depicting urban art as a lure for the creative class (Florida 2003; McAuliffe 2012).

While economic claims often underpin conspicuous flagship projects with huge budgets, community art projects have gained currency in smaller-scale neighborhood-based regeneration projects (Hall and Robertson 2001: 8; Wang et al. 2004). Such projects are often advanced by city councils, activist groups and local associations for social and cultural reasons rather than economic ones. The assumption underpinning such efforts is that public art can instill civic pride, foster 
social interaction, promote a sense of community, contribute to local identity and tackle social exclusion (Miles 1997; Rose 1997; Sharp et al. 2005; Simpson 2011).

In the last decade, geographers have therefore started to explore the critical politics of public art. Theorizing art as a norm-defying practice 'based on the refusal to accept current conditions as inevitable and natural' (Pinder 2008: 736) or as 'a provocative entry point for democratizing nature and developing a broader revolutionary politics' (Loftus 2009: 236), they have focused, in particular, on the way artists use public art and public space to articulate and communicate their interests and identities (Hawkins 2010a). These engagements are based on the conviction that art cannot only challenge, question, displace, destabilize and overturn the status quo in a society, but also open up a space for radical alternatives and different futures (Beyes 2010; Hawkins 2010b). Drawing upon this conviction, geographers have even come to incorporate public art in their own research practices (e.g. Strack et al. 2004; Dwyer and Davies 2010; Tolia-Kelly 2012).

However, the economic, social, cultural and political claims about the impacts of art in public spaces are often criticized for being overblown and unrealistic. More than a decade ago, Hall and Robertson (2001: 18) remarked that the renaissance of public art embedded in the cultural entrepreneurialism of neo-liberal policy-makers was based on its supposed contribution to urban regeneration, while 'very little satisfactory evaluation of these claims has taken place'. More recently, Pinder (2008: 733) confirmed that 'in underlining the potential significance of artistic interventions for developing critical perspectives on urban questions, there are risks of simplistic celebration or romanticization'. Considering the political claims about public art, it is problematic that the actual agency of public art - that what happens when art is 'out there' in public space - is barely understood. In particular, the way art and artists interact with audiences and publics remains a black box for geographers (Hall 2003; Zebracki et al. 2010). Nonetheless, as Hawkins (2012, p. 6) claims:

"it is what these forms of art 'do', or are claimed to 'do', in terms of building communities and places, but also in the name of radical politics, that lends a critical and political imperative to their investigation. These are investigations that geographers' re-imaginations of site and politics are well positioned both to benefit from and to contribute to."

This special issue aims to open up the black box of what we will call the 'sociopolitics' of public art. Each of the papers discusses in detail the way art becomes political not through overt struggle, but through fine-grained micro-cultural and discursive processes of exchanging meanings and ideas (see Beyes, 2010). They disentangle the complex connections between the intentions of artists and curators, the materialization of their artworks, their reception by the public and their political effects.

To do so, the four papers in this issue draw on insights from the rich field of public pedagogy. In this introductory article we will argue how public pedagogy, in particular its more programmatic strand, provides geographers with strong conceptual tools to analyze these socio-political processes. In the next paragraph, we introduce our perspective on public pedagogy and its contribution to the understanding of public art's socio-politics. Next, we will highlight the way public pedagogy has contributed to 
geographical perspectives on public art in the different articles. We end this introduction with a call for a wider engagement with public pedagogy in social and cultural geography, beyond the realm of public art.

\section{Public art and public pedagogy}

It is crucial to acknowledge that public pedagogy has never been a consolidated field or discipline (Sandlin et al. 2011). Nonetheless, the public pedagogy tradition we mobilize deviates from the dominant, analytical approach to public pedagogy which follows Henry Giroux (2004) in focusing on the study of media, popular culture and society as 'educative forces'. Rather, our inspiration draws from an emerging, more programmatic strand of literature which aims at deliberative, active political interventions in society and emphasizes that there is 'educational work' to be done in and for the public sphere (e.g. Biesta, forthcoming). This public pedagogy scrutinizes the educational processes involved when issues and interests are made 'public'. It focuses on the concrete practices of citizens engaged corporeally in social interactions which unsettle established notions of living together.

Whereas social and cultural geographers have only recently started to become truly interested in art, public pedagogy and educationalists in general have always had a deep interest in different art forms. Art and other cultural practices are considered to initiate learning processes which differ fundamentally from those generated in the context of formal schooling (Sandlin et al. 2011: 364). This perspective redirects art research from exploring the meaning 'embedded' in art works to consider the sociopolitical processes of learning stimulated by art. The processes under scrutiny range from the creation of opportunities to enact the public quality of human togetherness (Biesta, 2012) over the emotionally charged challenges posed by artists to securities and established convictions (Ellsworth, 2005) to the way art opens up new ways of seeing, feeling, experiencing and describing the world (Rancière, 2010).

While the pedagogical and political processes of art under scrutiny vary across public educationalists, the angle from which these processes are approached is shared. Public pedagogy emphasizes how educators (e.g. artists) cannot merely impose meaning or singular answers upon their educational subjects. Instead, public pedagogy through art is about creating 'transitional spaces' where individuals are challenged to face the ambivalences that result from encounters with diversity (Biesta 2004; Ellsworth 2005; Masschelein 2010). In Rancière's (2009: 11) terms, the artist is an 'ignorant schoolmaster' who 'does not teach his pupils his knowledge, but orders them to venture into the forest of things and signs to say what they have seen and what they think of what they have seen, to verify it and have it verified'.

These insights from educationalists could strengthen public art geographies in two specific ways. First of all, educationalists encourage geographers to shift their focus from the artists and the artworks per se towards the way audiences engage with art. By exploring these engagements as moments of learning, public pedagogy also provides us with the theoretical and analytical tools to understand the socio-political processes involved. Secondly, public pedagogy stimulates geographers to reconsider the role of the artist or curator. Instead of a 'spokesperson' giving voice to particular interests, the artist is considered an 'educator' who engages with audiences and 
settings of the artwork in interactive and complex ways. As such, public pedagogy stimulates us to throw an alternative light on the processes of place-making through public art. In the next section, we will detail the different ways in which each of the four papers in this collection fulfills this aim.

\section{Introducing the papers}

In this special issue, geographers and educationalists explore the attempts of artists to engage with place-making through artistic interventions in public space (cf. Pinder 2005; 2008, Loftus 2009). In so doing, they analyze the connections between public art, public space and public pedagogy. Looking at various art forms with multiple methodologies, they draw on a diverse set of theories and focus on different educational moments. Hence, the special issue does not only speak of a wide variety of theoretical, methodological and empirical perspectives on art. It also contains a broad view on the linkages between art and politics, artists and audiences or artworks and places.

The first paper discusses the Permanent Breakfast initiative. It concerns an artistic intervention reflecting on the publicness of public art by setting up a worldwide chain of breakfasts in public spaces. In the paper, Biesta (2012) refers to Hannah Arendt's definitions of politics, freedom and the public sphere and identifies three different notions of public pedagogy: a pedagogy for the public, a pedagogy of the public and a pedagogy that enacts a concern for 'publicness'. For Biesta, the first two forms of public pedagogy run the risk of undermining the political by conceiving of public pedagogy as a form of instruction or teaching. Enacting a concern for publicness, on the other hand, is about opening up opportunities for 'becoming public'. Permanent Breakfast, albeit an insignificant intrusion, represents this third notion. It does not present political claims itself. Instead, breakfasting in public space enables audiences and performers to understand, practice and experience publicness.

The second paper compares two photographic exhibitions set up by community workers in Ghent (Belgium) and Bonnybridge (Scotland). It engages with Biesta's threefold division of public pedagogies to reveal the complex relationships between artists, curators, artworks and audiences and to critically assess the political ambitions and potentials of community art projects and their 'curators-educators'. In both cases, community workers explicitly aim at changing the character and identity of their places of operation through photographs. Yet, the analysis of Loopmans, Cowell and Oosterlynck (2012) reveals the strategic challenges they are confronted with and explores how photographic interventions combine a complex set of social processes which reflect the inherently relational character of place-making. The socio-political processes unfolding from artistic interventions cannot be planned beforehand and require constant negotiation and reflection over content, reach and site.

Ding and Schuermans (2012) further develop the question of the socio-political ambitions of critical public art in their account of what was claimed to be the first ever art exhibition in a Chinese chengzhongcun ('Village-in-the-City' or migrant slum)). Their exploration of the relation between art and citizenship politics is guided by geographical and pedagogical readings of the work of Jacques Rancière (2009, 
2010) and discusses the silent socio-political strategies of the Hefei art biennale which conveys a critical message on the discrimination of rural-to-urban migrants in China. Analyzing the performances, the pictures and the installations in the art exhibition and their reception by visitors, journalists and contributors to online forums, the powerful political potential for Chinese citizenship struggles of open-ended and 'aestheticized' pedagogy of the Hefei exhibition is revealed. More than other forms of urban protest, public art can stimulate new modes of perceiving and sensing while avoiding to 'teach' an explicit critique.

The final paper by Zebracki (2012) discusses the local reception of 'Santa Claus', a 4500 kilogram heavy bronze statue by Paul McCarthy situated in the city of Rotterdam, the Netherlands. Zebracki reveals the plurality of audiences and their engagement with the artwork before and after the statue moved from the courtyard of a museum to an inner city public square. The permanent and monumental piece of public art is discussed as a long-term pedagogical intervention entailing issues of education, meditation and emancipation embedded within broader socio-political agendas and affects. In line with Loopmans et al (2012), Zebracki shows how audiences react differently depending upon their social, economic and political relations to both the artwork and its place. Dwelling upon Haraway's (1991) concept of situated knowledges, Zebracki discusses the artwork as a screen on which different socio-spatial relations are mapped (Morris and Cant, 2006). His paper stirs reflection about the artwork, its locale and the relations between them.

\section{Taking a public pedagogy 'turn'}

The four papers in this special issue reveal what can be learnt when art geographies engage with public pedagogy. The contributors emphasize how place-making through art is a 'socio-political' process operating through fine-grained cultural processes which guide our way of thinking and acting (cf. Martin 2003; Beyes 2010). Educationalists have helped us to grasp the socio-politics of art as moments of education and opportunities for learning.

Public pedagogy provides us with the theoretical tools to disentangle the plural, shifting, open and contested ways of the socio-political 'making of places' by artists and to understand their role as 'educators' when intervening in localized struggles for more freedom, more equality or better citizenship rights. Having emphasized the merit of public pedagogy to understand art, this issue also asserts that public pedagogy could contribute to social and cultural geographies of place and identitymaking in at least three important ways.

Firstly, the papers in this issue contribute to the emerging literature on the sociopolitics of relational place-making (Martin, 2003; Massey, 2005; Pierce et al, 2011; Hankins et al., 2012). Loopmans et al., Ding and Schuermans and Zebracki discuss the discursive struggles over local identity as complex 'learning processes' and draw from public pedagogy a political understanding of the way meanings and identities are conveyed and shared. Their engagement with public pedagogy allows for a more detailed understanding of the fine-grained everyday politics of relational placemaking and brings to the fore issues of power inequality, cultural destabilization and social exclusion in and through the materialities of space (see McFarlane 2011). 
Secondly, Biesta, Ding and Schuermans and Loopmans et al. talk to the 'geographies of encounter' literature (Amin, 2002; Iveson, 2006; Valentine, 2008; Schuermans, 2011). Drawing from public pedagogy, they discuss the role of educational agents in stimulating or unsettling what appear to be 'spontaneous' learning processes in relation to living with difference. Public pedagogy, with its political perspective on everyday learning, might provide ways to scrutinize the conundrum identified by Valentine (2008) of how we can 'scale up' meaningful micropublic encounters to a new notion of citizenship which respects difference.

Thirdly, this collection emphasizes that public pedagogy provides us with innovative tools and insights to conceive of and strife for social and spatial justice. A public pedagogy perspective can provide us with practical suggestions on how to politicize geographical research and seek out 'what is to be done' to create openings for new understandings and political demands towards more just places (Freire, 1970; 1998; Biesta, 2012b; Wildemeersch, 2012; Gourd \& Gourd, 2011; Ruitenberg, 2012).

Hence our call and ambition, at the end of this introduction, is to promote a 'public pedagogy turn' in geographical studies of art, as well as in social and cultural geography at large.

\section{Acknowledgements}

We would like to thank the anonymous referees, the contributors to this special issue and all other geographers, educationalists and artists gathered in the Scientific Research Community 'Diversity and Plurality in Urban Contexts' for their insightful comments on earlier versions of this paper. We are also indebted to Phil Hubbard and Michael Brown for making this issue possible. Special thanks go to the Flemish Research Council FWO for sponsoring our international collaboration in the Scientific Research Community.

\section{References}

Amin A. (2002) Ethnicity and the multicultural city: living with diversity. Environment and Planning $A 34$, 959-80.

Amin A. (2008) Collective culture and urban public space, City: analysis of urban trends, culture, theory, policy, action 12, 5-24.

Beyes T. (2010) Uncontained: The art and politics of reconfiguring urban space, Culture and Organization 16, 229-246.

Biesta G. (2004) The community of those who have nothing in common. Education and the language of responsibility, Interchange 35, 307-324.

Biesta G. (2012a) Becoming public: Public pedagogy, citizenship and the public sphere, Social \& Cultural Geography, this issue 
Biesta G. (2012b), Philosophy of Education for the Public Good: Five Challenges and an Agenda, Educational Philosophy and Theory, article first published online, DOI: 10.1111/j.1469-5812.2011.00783.x

Biesta G. (forthcoming) Emancipation, public pedagogy and the politics of learning. In Burdick, J., Sandlin, J.A. \& O'Malley (Eds), Problematizing Public Pedagogy. New York: Routledge.

Burk A.L. (2006) Beneath and before: Continuums of publicness in public art, Social \& Cultural geography 7, 949-964.

Butler T. (2006) A walk of art: the potential of the sound walk as practice in cultural geography, Social \& Cultural Geography, 7, 889-908

Cosgrove D. (1985) Prospect, perspective and the evolution of the landscape idea, Transactions of the Institute of British Geographers 10, 45-62.

Cresswell T. (1992) The crucial 'where' of graffiti: A geographical analysis of reactions to graffiti in New York, Environment and Planning D 10, 329-344.

Currid E. (2010) Art and economic development: New directions for the growth of cities and regions, Journal of Planning Education and Research 29, 257-261.

Darts D. (2006) Art education for a change: Contemporary issues and the visual arts, Art Education 5, 6-12.

Daya S. (2011) Performing place. Mobility and identity in South Africa, Area 34, 488494.

DeSilvey C. (2010) Memory in motion: Soundings from Milltown, Montana, Social \& Cultural Geography 11, 491-510.

Ding Y. and Schuermans N. (2012) "Happiness Hefei": Public art and rural-urban citizenship struggles in transitional China, Social \& Cultural Geography this issue

Dwyer C. and Davies G. (2010) Qualitative methods III: Animating archives, artful interventions and online environments, Progress in Human Geography 34, 88-97.

Ellsworth E. (2005) Places of learning: Media, architecture, pedagogy. New York: Routledge.

Florida R. (2003) Cities and the creative class, City \& Community 2, 3-19.

Freire P. (1970) Pedagogy of the oppressed. New York, NY: Continuum.

Freire P. (1998) Pedagogy of freedom: Ethics, democracy, and civic courage. (P. Clarke, Trans.). Lanham, MD: Rowman \& Littlefield.

Giroux H. A. (2001) Cultural studies as performative politics, Cultural Studies <=> Critical Methodologies 1, 5-23.

Gourd K. M., and Gourd T. Y. (2011), Enacting Democracy: Using Forum Theatre to Confront Bullying, Equity \& Excellence in Education, 44:3, 403-419 
Hall T. and Robertson I. (2001) Public art and urban regeneration: Advocacy, claims and critical debates, Landscape Research 26, 5-26.

Hall T. (2003) Opening up public art's spaces: Art, regeneration and audience, in Miles, M. (ed.) Cultures and Settlements: Advances in Art and Urban Futures. Bristol: Intellect Press, pp. 49-57.

Hankins K.B., Cochran R. and Derickson K.D. (2012) Making space, making race: reconstituting white privilege in Buckhead, Atlanta, Social and Cultural Geography, 13 (4), 379-397.

Haraway D. (1991) Simians, Cyborgs, and Women: The Reinvention of Women. New York: Routledge.

Harvey D. (1989) The condition of postmodernity, Oxford: Blackwell

Hassink R. (2005) How to unlock regional economies from path dependency? From learning region to learning cluster, European Planning Studies 13, 521-535.

Hawkins H. (2010a) 'The argument of the eye'? The cultural geographies of installation art, Cultural Geographies 17, 321-340.

Hawkins H. (2010b) Turn your trash into ... Rubbish, art and politics. Richard Wentworth's geographical imagination, Social \& Cultural Geography 11, 805-827.

Hawkins H. (2012) Geography and art. An expanding field: site, the body and practice, Progress in Human Geography, DOI: 10.1177/0309132512442865.

Iveson K. (2006) Strangers in the cosmopolis. In Binnie,J., Holloway, J., Millington, S. and Young, C.,editors, Cosmopolitan urbanism, London: Routledge.

Johnson N. (1995) Cast in stone: Monuments, geography, and nationalism, Environment and Planning D 13, 51-65.

Landry C. and Bianchini F. (1995) The Creative City. London: Demos.

Loftus A. (2009) Intervening in the environment of the everyday, Geoforum 40, 326334.

Lombard M. (2012) Using auto-photography to understand place: reflections from research in urban informal settlements in Mexico. Area. doi: 10.1111/j.14754762.2012.01115.x

Loopmans M., Cowell G. and Oosterlynck S. (2012) Photography, public pedagogy and the politics of place-making in post-industrial areas, Social \& Cultural Geography this issue

Martin D. (2003) Enacting neighborhood, Urban Geography 24, 361-85.

Masschelein J. (2010) E-ducating the gaze: The idea of a poor pedagogy, Ethics and Education 5, 43-53.

Massey D. (2005) For Space. London, Sage. 
McAuliffe C. (2012) Graffiti or street art? Negotiating the moral geographies of the creative city, Journal of Urban Affairs 34, 189-206.

McFarlane F. (2011) Learning the city. Knowledge and translocal assemblage. Malden: Wiley-Blackwell.

Miles M. (1997) Art, space and the city: Public art and urban futures, London: Routledge.

Molotch H. and Teskov M. (2009) Changing art: SoHo, Chelsea and the dynamic geography of galleries in New York City, International Journal of Urban and Regional Research 33, 517-541.

Morgan K. (1997) The learning region: Institutions, innovation and regional renewal, Regional Studies 31, 491-503.

Morris N.J. and Cant S.G. (2006) Engaging with place: Artists, site-specificity and the Hebden Bridge Sculpture Trail, Social \& Cultural Geography 7, 863-888.

Neate H. (2012) Provinciality and the art world: The Midland Group, 1961-1977, Social \& Cultural Geography 13, 275-294.

Pinder D. (2005) Arts of urban exploration, Cultural Geographies, 13, 383-411.

Pinder D. (2008) Urban interventions: Art, politics and pedagogy, International Journal of Urban and Regional Research, 32, 730-736.

Pinder D. (2011) Errant paths: The poetics and politics of walking, Environment and Planning D 29, 672-692.

Rancière J. (2009) The emancipated spectator. London: Verso.

Rancière J. (2010) Dissensus. On politics and aesthetics. London: Continuum.

Rees R. (1976) John Constable and the art of geography, Geographical Review 66, 59-72.

Rose G. (1996) Teaching visualized geographies: towards a methodology for the interpretation of visual materials, Journal of Geography in Higher Education, 20 (3), 281-294

Rose G. (1997) Spatialities of 'community', power and change: The imagined geographies of community art projects, Cultural Studies 11, 1-16.

Rose, G. (2006) Visual methodologies: an introduction to the interpretation of visual materials. London: Sage.

Ruitenberg C. W. (2012): Learning by walking: non-formal education as curatorial practice and intervention in public space, International Journal of Lifelong Education, $31: 3,261-275$

Sandlin J. and Milam J. (2008) Mixing Pop (Culture) and Politics: Cultural Resistance, Cultural Jamming, and Anti-Consumption Activism as Critical Public Pedagogy, Curriculum Inquiry,38, 323-350. 
Sandlin J.A., O'Malley M.P. and Burdick J. (2011) Mapping the complexity of public pedagogy scholarship 1894-2010, Review of Educational Research 81, 338-375.

Schuermans N. (2011) Anxieties, identities and spatialities, ambivalent geographies of encounter in Cape Town and Flanders, unpublished PhD-thesis, Leuven: KULeuven.

Sharp J., Pollock V. and Paddison R. (2005) Just art for a just city: Public art and social inclusion in urban regeneration, Urban Studies, 42, 1001-1023.

Simpson P. (2011) Street performance and the city: Public space, sociality, and intervening in the everyday, Space and Culture 14, 415-430.

Strack R.W., Magill C. and McDonagh, K. (2004) Engaging youth through photovoice, Health Promotion Practice 5, 49-58.

Tolia-Kelly D.P. (2012) The geographies of cultural geography II: Visual culture, Progress in Human Geography 36, 135-142.

Valentine G. (2008) Living with difference: Reflections on geographies of encounter, Progress in Human Geography 32, 323-337.

Wang C.C., Morrel-Samuels S., Hutchison P.M., Bell L. and Pestronk, R.M. (2004) Flint photovoice: Community building among youths, adults, and policymakers. American Journal of Public Health 94, 911-913.

Wildemeersch D. (2012): Imagining pedagogy in public space: visions of cultural policies and practices in a city in transformation, International Journal of Lifelong Education, 31:1, 77-95

Zebracki M. (2012) Engaging geographies of public art: Indwellers, the 'Butt Plug Gnome' and their locale, Social \& Cultural Geography this issue

Zebracki M., Van Der Vaart, R., Van Aalst I. (2010) Deconstructing public artopia: Situating public-art claims within practice, Geoforum 41, 786-795. 